\title{
Deciphering lignocellulose deconstruction by the white rot fungus Irpex lacteus based on genomic and transcriptomic analyses
}

\author{
Xing Qin ${ }^{1,2+}{ }^{2}$ Xiaoyun Su${ }^{1 *+}$, Huiying Luo ${ }^{1}$, Rui Ma ${ }^{1}$, Bin Yao ${ }^{1 *}$ and Fuying Ma ${ }^{2^{*}}$
}

\begin{abstract}
Background: Irpex lacteus is one of the most potent white rot fungi for biological pretreatment of lignocellulose for second biofuel production. To elucidate the underlying molecular mechanism involved in lignocellulose deconstruction, genomic and transcriptomic analyses were carried out for l. lacteus CD2 grown in submerged fermentation using ball-milled corn stover as the carbon source.

Results: Irpex lacteus CD2 efficiently decomposed 74.9\% lignin, 86.3\% cellulose, and 83.5\% hemicellulose in corn stover within 9 days. Manganese peroxidases were rapidly induced, followed by accumulation of cellulase and hemicellulase. Genomic analysis revealed that I. lacteus CD2 possessed a complete set of lignocellulose-degrading enzyme system composed mainly of class II peroxidases, dye-decolorizing peroxidases, auxiliary enzymes, and 182 glycoside hydrolases. Comparative transcriptomic analysis substantiated the notion of a selection mode of degradation. These analyses also suggested that free radicals, derived either from MnP-organic acid interplay or from Fenton reaction involving $\mathrm{Fe}^{2+}$ and $\mathrm{H}_{2} \mathrm{O}_{2}$, could play an important role in lignocellulose degradation.
\end{abstract}

Conclusions: The selective strategy employed by I. lacteus CD2, in combination with low extracellular glycosidases cleaving plant cell wall polysaccharides into fermentable sugars, may account for high pretreatment efficiency of I. lacteus. Our study also hints the importance of free radicals for future designing of novel, robust lignocellulosedegrading enzyme cocktails.

Keywords: Irpex lacteus, Lignocellulose, Transcriptomics, Manganese peroxidase, Free radicals

\section{Background}

The white rots are a large group of fungi that can efficiently decompose plant cell wall and utilize all its components including lignin, cellulose, and hemicellulose. The white rot fungi depend mainly on oxidoreductases and glycoside hydrolases for lignin and polysaccharides degradation, respectively [1]. In contrast, brown rot fungi selectively degrade carbohydrates, owing to the lack of ligninolytic enzymes such as class II peroxidases

\footnotetext{
*Correspondence: suxiaoyun@caas.cn; binyao@caas.cn; mafuying@hust.edu.cn

${ }^{+}$Xing Qin and Xiaoyun Su contributed equally to this work

1 Key Laboratory for Feed Biotechnology of the Ministry of Agriculture, Feed Research Institute, Chinese Academy of Agricultural Sciences, No. 12 South Zhongguancun Street, Beijing 100081, People's Republic of China ${ }^{2}$ College of Life Science and Technology, Huazhong University of Science and Technology, Wuhan 430074, People's Republic of China
}

and laccases [2-4]. Due to their superior capability in destructing lignocellulose, white rot fungi can be widely used in many biotechnological industries including biofuel and biorefinery, especially in the biological pretreatment of lignocellulosic biomass feedstock [5].

With the advancement in next generation sequencing, whole genome sequencing is widely used to explore the underlying molecular mechanisms of lignocellulose degradation by white rot fungi $[6,7]$. To date, dozens of white rot fungal genomes, such as those from Phanerochaete chrysosporium and Ceriporiopsis subvermispora, have been sequenced and are publicly available [8]. Comparative genomic studies have revealed that class II peroxidases, dye-decolorizing peroxidases (DyPs), and multiple pathways for hydrogen peroxide $\left(\mathrm{H}_{2} \mathrm{O}_{2}\right)$ production collectively constitute the ligninolytic enzyme 
system in white rots [9]. With these achievements, multiomics analyses are emerging as an integrated approach to deepen our understanding of enzymatic degradation of lignocellulose by white rots. In recent years, there have been reports of using multi-omics to analyze $P$. chrysosporium grown on aspen, pine, and spruce [10-12], $C$. subvermispora on aspen [13], Pycnoporus coccineus on aspen and pine [14], Phlebia radiata on spruce [15], and Dichomitus squalens on aspen, spruce, wheat bran, and cotton seed hulls [16]. These studies mainly focused on gene expression patterns in response to different lignocelluloses or times.

White rot fungi are further grouped into simultaneous and selective lignocellulose degraders [17]. The former class, represented by $P$. chrysosporium, simultaneously removes cellulose, hemicellulose, and lignin. The selective degraders, typified by C. subvermispora, instead preferentially destroy lignin rather than cellulose and hemicellulose at the early stage [18]. Correspondingly, cellulase is expressed at a constant but high level, while lignin-degrading enzymes gradually accumulate in $P$. chrysosporium confronting lignocellulose [12]. In contrast, $C$. subvermispora secrets mainly peroxidases oxidizing lignin initially, then switches to carbohydrate active enzymes (CAZymes) acting on cellulose and hemicellulose at the advanced stage [13].

The simultaneous and selective paradigms of white rots are defined primarily based on their degradation patterns associated with woody lignocellulose. Interestingly, Irpex lacteus $\mathrm{CD} 2$, a white rot basidiomycete with potent lignocellulose-degrading ability [19], displays a degradation pattern similar to the selective paradigm in pretreating the corn stover. I. lacteus CD2 preferentially degrades lignin at the early stage, followed by sharply elevated cellulose degradation rate at the advanced stage [19]. The same pattern has also been reported recently for degradation of corn stover by another I. lacteus strain Fr. 238 $617 / 93$ [20]. Recently, the genome of an I. lacteus strain F17 was reported [21]. The secretome of I. lacteus strain Fr. 238 617/93 grown on wheat straw has also been studied [22]. These investigations undoubtedly deepen our understanding of lignocellulose degradation by I. lacteus. However, with these achievements, the molecular mechanism underlying the selective-like mode of lignocellulose degradation by I. lacteus and its implication remain unknown. The genomic information of I. lacteus has not yet been linked to transcription of genes relevant to lignocellulose degradation. There are no systematic analyses available for I. lacteus CD2 (and other strains) grown on corn stover, which is an agricultural residue produced in large amounts and can be used as a feedstock for second-generation biofuels [23]. Herein, the genome of $I$. lacteus CD2 was sequenced and analyzed, combing with biochemical and transcriptomic analyses to elucidate the molecular mechanism on its efficient deconstruction of lignocellulose in corn stover.

\section{Results \\ Genome sequencing of I. lacteus CD2 and evolutionary analysis}

We sequenced the genome of I. lacteus CD2 to a 79-fold coverage using a combination of Illumina HiSeq 2000 platform and the PacBio RS 3rd generation technology. The genome of I. lacteus CD2 was distributed in 280 contigs with an assembly of $43.16 \mathrm{Mb}$. More than half of the total sequence and $69 \%$ of the 10,853 predicted genes were in the six largest contigs. Above 92\% of the genes could be assigned with a definitive function through homology search against the KEGG, KOG, GO, NR, UniProt, and Tremble databases. The summaries of functional annotations of the genome and the top 50 PFAM domains are shown in Additional files 1 and 2 , respectively. Similar to the findings in other white rot fungi, signaling proteins, cytochrome P450 monooxygenases (P450s), and major facilitator superfamily (MFS) transporters constituted the largest families and played important roles in the biosynthesis and transportation of metabolites [24, 25]. Thirty-five sugar transporters, members of the MFS transporters indispensable for cellulose and hemicellulose utilization, were among the top domains in I. lacteus CD2 (Additional file 2).

The phylogenomic analysis provides an overview of evolutionary relationship with different strains, serving as a roadmap for its future studies. 987 single-copy orthologous genes were identified in I. lacteus CD2 and the other eight sequenced Polyporales. The amino acid sequences of these orthologs were aligned using MAFFT for phylogenetic reconstruction. Maximum likelihood analysis of these genes resulted into a tree with nearly identical topologies (Fig. 1). In the phylogenetic tree, all the nodes had a $100 \%$ maximum likelihood bootstrap value. I. lacteus $\mathrm{CD} 2$ was evolutionarily most close to the lignocellulose degraders Bjerkandera adusta, P. carnosa, and $P$. chrysosporium.

\section{Lignin-degrading oxidoreductive enzymes}

The chemical reactions involved in lignin modification by white rot fungi were mainly oxidoreduction $[26,27]$. Sixty-two gene models were predicted to encode lignocellulose-degrading oxidoreductases in I. lacteus CD2 (Additional file 3), among which nine were fungal class II peroxidases and four were DyPs. In contrast to T. versicolor, D. squalens, Ganoderma sp., and C. subvermispora, I. lacteus CD2 lacked laccase (AA1_1), which is able to cleave various kinds of linkage in lignin in the presence of appropriate mediators [28]. However, I. lacteus CD2 


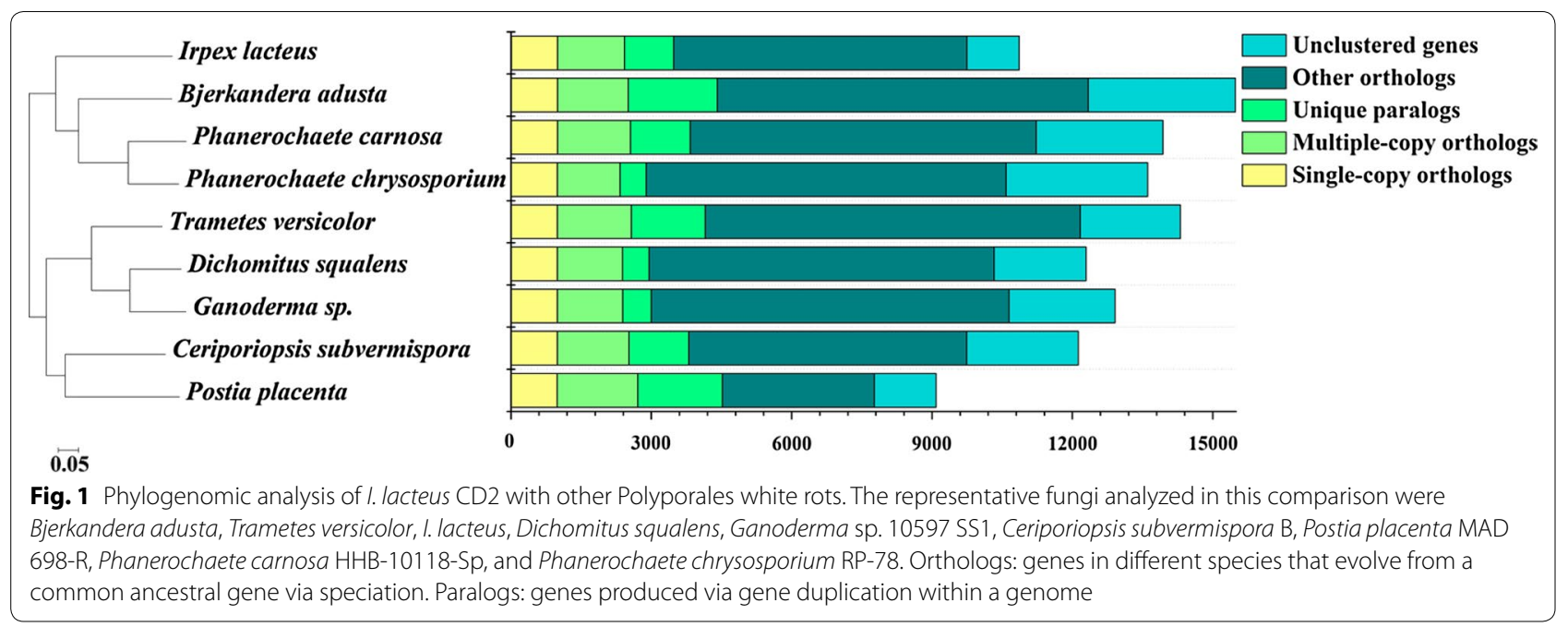

had DyPs (Additional file 3), which deconstruct phenolic and non-phenolic lignin to facilitate enzymatic saccharification of lignocellulose [29]. In addition to peroxidases, I. lacteus CD2 encoded 22 glucose methanol choline (GMC) oxidoreductases (AA3) and seven copper radical oxidases (AA5) involved in extracellular $\mathrm{H}_{2} \mathrm{O}_{2}$ generation (Additional file 3). These GMC oxidoreductases were further classified into four groups: one cellobiose dehydrogenase (CDH, AA3_1), sixteen aryl alcohol oxidases (AAO, AA3_2), four alcohol oxidases (AOX, AA3_3), and one pyranose-2-oxidase (POX, AA3_4).

\section{Auxiliary enzymes involved in lignin degradation and metabolism}

Meanwhile, various low molecular weight compounds including heme, veratryl alcohol (VA), and oxalate were involved in stimulating ligninolytic enzymes production and depolymerizing lignin [26]. Heme was considered as one critical limiting factor for the production of class II peroxidases and P450s [30, 31]. In I. lacteus CD2, heme was predicted to be generated from eight consecutive enzymatic reactions and might be regulated by siroheme biogenesis pathway (Additional file 4). VA also played a significant role in the regulation of synthesis of lignocellulose-degrading enzymes [32]. Presumptively, VA was produced through the non-oxidative phenylalanine degradation and the $\beta$-oxidation pathways. The related enzymes of I. lacteus CD2 were phenylalanine ammonia lyase, AAO, aryl alcohol dehydrogenase, and aryl aldehyde dehydrogenase [33]. Besides, oxalate was normal fungal metabolites facilitating lignin degradation in multiple ways, including chelating unstable $\mathrm{Mn}^{3+}$ ions, producing $\mathrm{H}_{2} \mathrm{O}_{2}$, and lowering $\mathrm{pH}$ for optimal performance of the ligninolytic enzymes [26, 34]. Four glyoxylate dehydrogenases and two oxaloacetases were discovered to participate in generating oxalate from glyoxylate and oxaloacetate in I. lacteus CD2, respectively (Additional file 5). On the other hand, three oxalate decarboxylases and one oxalate oxidase were predicted to be responsible for decomposition of oxalate.

In addition, P450s are indispensable in intracellular metabolism of lignin metabolites and related compounds, and widely distributed in the white rots [35]. The 130 P450s genes of I. lacteus CD2 could be grouped into 8 clans containing 17 families with a large portion of the members originating from gene duplication [36]. I. lacteus CD2 showed an expansion of the CYP53 clan P450 members involved in lignin metabolism, compared with that in model white rot fungus $P$. chrysosporium $[37,38]$.

\section{Carbohydrate active enzymes involved in Plant cell wall polysaccharides degradation}

Irpex lacteus CD2 encoded a total of 273 CAZymes, which could be grouped into 182 glycoside hydrolases (GHs), 66 glycosyltransferases (GTs), 5 polysaccharide lyases (PLs), and 20 carbohydrate esterases (CEs), respectively. The cellulose-degrading GHs in I. lacteus CD2 consisted of cellobiohydrolases (GH6 and GH7), endoglucanases (GH5, GH9, GH12, GH44, and GH45), and $\beta$-glucosidases (GH1 and GH3). The hemicellulosedegrading GHs were composed of xylanases (GH10), xylosidase (GH43), arabinofuranosidase (GH51), and acetylxylan esterase (CE1).

Except for enzymatic hydrolysis, the oxidative cleavage by lytic polysaccharide monooxygenases (LPMOs) was another important route to promote polysaccharide degradation $[39,40]$. I. lacteus CD2 encoded 17 LPMOs potentially involved in stimulating cellulose and/or hemicellulose degradation [41]. Fifteen of these LPMOs have a C-terminal extension appending 
to the AA9 core domain with the lengths ranging from 15 to 121 amino acids and four LPMOs have an additional carbohydrate-binding module 1 (CBM1) that might display higher cellulose degradation capability [42].

Interestingly, the CAZyme genes were non-randomly distributed in the I. lacteus CD2 genome. Instead, they existed in cluster, particularly for those enzymes belonging to the same CAZyme family. These included a triplet of GH10, a triplet of GH43, a pair of GH5, and a pair of GH18 genes (Additional file 6). None of these adjacent genes appeared to be paralogs, again indicative of frequent gene duplication events during evolution of I. lacteus CD2.
Genes for generating free radicals involved in lignocellulose degradation

Different types of free radicals, mainly the hydroxyl radical, fatty acid peroxyl radicals, carboxylate-derived radicals, and superoxide radical, are well known for their implication in lignocellulose degradation [43, 44]. In particular, the hydroxyl radical produced in Fenton reaction by $\mathrm{Fe}^{2+}$ and $\mathrm{H}_{2} \mathrm{O}_{2}$ is highly reactive, attacking both lignin and cellulose [28]. Iron transportation and reduction hence significantly affect the rate of Fenton reaction. Genes encoding siderophore iron transporters, ferroxidase-permeases, reductase/permeases, and manganese transporters, all of which contribute to iron uptake, were found in the genome of I. lacteus CD2 (Table 1).

Table 1 Genes and their transcription levels relating to metabolism of iron, oxalate, and unsaturated fatty acid, which are involved in free radical generation in I. lacteus CD2

\begin{tabular}{|c|c|c|c|c|c|c|}
\hline \multirow[t]{2}{*}{ Metabolic pattern } & \multirow[t]{2}{*}{ Gene } & \multirow[t]{2}{*}{ Putative function } & \multicolumn{4}{|l|}{ FPKM } \\
\hline & & & Glu3d & Glu6d & LC3d & LC6d \\
\hline \multicolumn{7}{|l|}{ Iron transportation } \\
\hline \multicolumn{7}{|l|}{ High affinity } \\
\hline Siderophore-dependent & 0809.78 & Siderophore iron transporter & 77.7 & 32.8 & 12.7 & 47.1 \\
\hline \multirow[t]{4}{*}{ Reductase/ferroxidase-dependent } & 0809.292 & Ferric reductase & 113 & 46.0 & 29.5 & 160 \\
\hline & 0811.747 & Ferric reductase & 131 & 129 & 138 & 191 \\
\hline & 0809.825 & Ferroxidase Fet3 & 131 & 5.11 & 9.88 & 3.45 \\
\hline & 0809.824 & Permease Ftr1 & 158 & 8.63 & 4.10 & 4.12 \\
\hline \multicolumn{7}{|l|}{ Low affinity } \\
\hline \multirow[t]{2}{*}{ Reductase/permease-dependent } & 0807.394 & Manganese transporter SMF2 & 17.5 & 36.7 & 17.7 & 6.32 \\
\hline & 0925.691 & Manganese transporter pdt1 & 54.7 & 148 & 25.2 & 16.4 \\
\hline \multirow[t]{7}{*}{ Iron reduction } & 0811.251 & Cellobiose dehydrogenase & 5.54 & 3.81 & 42.9 & 150 \\
\hline & 0810.454 & Glycopeptide & 730 & 2764 & 3695 & 3820 \\
\hline & 0809.299 & 1,4-Benzoquinone reductase & 1392 & 4844 & 966 & 396 \\
\hline & 0809.746 & NADH-quinone oxidoreductase & 198 & 404 & 537 & 271 \\
\hline & 0808.232 & Quinate permease & 19.3 & 27.1 & 53.0 & 35.3 \\
\hline & 0808.329 & Quinate permease & 1.66 & 2.37 & 91.6 & 81.5 \\
\hline & 0821.194 & Quinate permease & 137 & 170 & 1218 & 3500 \\
\hline \multirow[t]{6}{*}{ Oxalate biosynthesis } & 0811.539 & Oxaloacetase & 7.83 & 207 & 103 & 77.2 \\
\hline & 0807.332 & Oxaloacetase & 50.1 & 291 & 277 & 264 \\
\hline & 0811.538 & Glyoxylate dehydrogenase & 5.21 & 174 & 6.35 & 7.59 \\
\hline & 0810.540 & Glyoxylate dehydrogenase & 36.6 & 55.0 & 106 & 66.7 \\
\hline & 0809.407 & Glyoxylate dehydrogenase & 57.6 & 66.5 & 187 & 127 \\
\hline & 0807.465 & Glyoxylate dehydrogenase & 28.9 & 78.2 & 116 & 69.3 \\
\hline \multirow[t]{4}{*}{ Oxalate degradation } & 0806.66 & Oxalate oxidase & 1231 & 825 & 33.0 & 2.66 \\
\hline & 0808.407 & Oxalate decarboxylase & 2.61 & 7.41 & 4.53 & 7.58 \\
\hline & 0816.66 & Oxalate decarboxylase & 131 & 160 & 2.26 & 8.10 \\
\hline & 1079.217 & Oxalate decarboxylase & 3.95 & 8.49 & 4.20 & 4.70 \\
\hline \multirow[t]{3}{*}{ Unsaturated fatty acid biosynthesis } & 0925.1168 & Delta(12) fatty acid desaturase & 24.5 & 14.1 & 1.15 & 1.41 \\
\hline & 0925.1167 & Delta(12) fatty acid desaturase & 813 & 950 & 90.0 & 106 \\
\hline & 0816.230 & Delta(9) fatty acid desaturase & 474 & 798 & 74.0 & 139 \\
\hline
\end{tabular}


In addition, genes coding for $\mathrm{CDH}$, glycopeptide, benzoquinone reductase, and quinate permease, which are involved in multiple pathways for $\mathrm{Fe}^{3+}$ reduction [45-47], were identified (Table 1). Fatty acid peroxyl radicals and carboxylate-derived radicals are generated from chelated $\mathrm{Mn}^{3+}$-mediated peroxidation of unsaturated lipid or oxidative decarboxylation of organic acids, respectively [43]. The genes related to fatty acid and oxalate metabolisms are listed in Table 1.

\section{Temporal changes in lignocellulose-degrading enzyme} activities of $I$. lacteus CD2 grown in lignocellulose medium Irpex lacteus $\mathrm{CD} 2$ was grown in liquid medium with ball-milled corn stover as carbon source. Since the accessibility of ball-milled lignocellulose was substantially increased [13], I. lacteus CD2 rapidly grew and efficiently decomposed $74.9 \%$ lignin, $86.3 \%$ cellulose, and $83.5 \%$ hemicellulose in corn stover within 9 days. Lignocellulose strongly induced expression of manganese peroxidases (MnPs), which are important enzymes involved in lignin degradation by white rots $[12,13,48]$, reaching maximal activities of $158 \mathrm{U} / \mathrm{L}$ (Fig. 2a) on day 3. Manganese-independent peroxidase (MIP) activity was $72 \mathrm{U} / \mathrm{L}$ (Fig. 2b). The activities of MnP and MIP sharply declined afterwards and completely diminished on day 5 . No lignin peroxidase (LiP) and DyP activity was detected throughout the cultivation. $\mathrm{CDH}$ is an enzyme with multiple roles in both lignin and cellulose degradation $[49,50]$. Minor $\mathrm{CDH}$ activity was observed from day 2 to day 4 , which sharply increased on day 5 and then slowly ascended (Fig. 2c). On the contrary, for plant cell wall polysaccharides degrading enzymes, the endoglucanase (EG) activity gradually increased to a maximal level on day 4 and remained nearly constant in the following days (Fig. 2d).
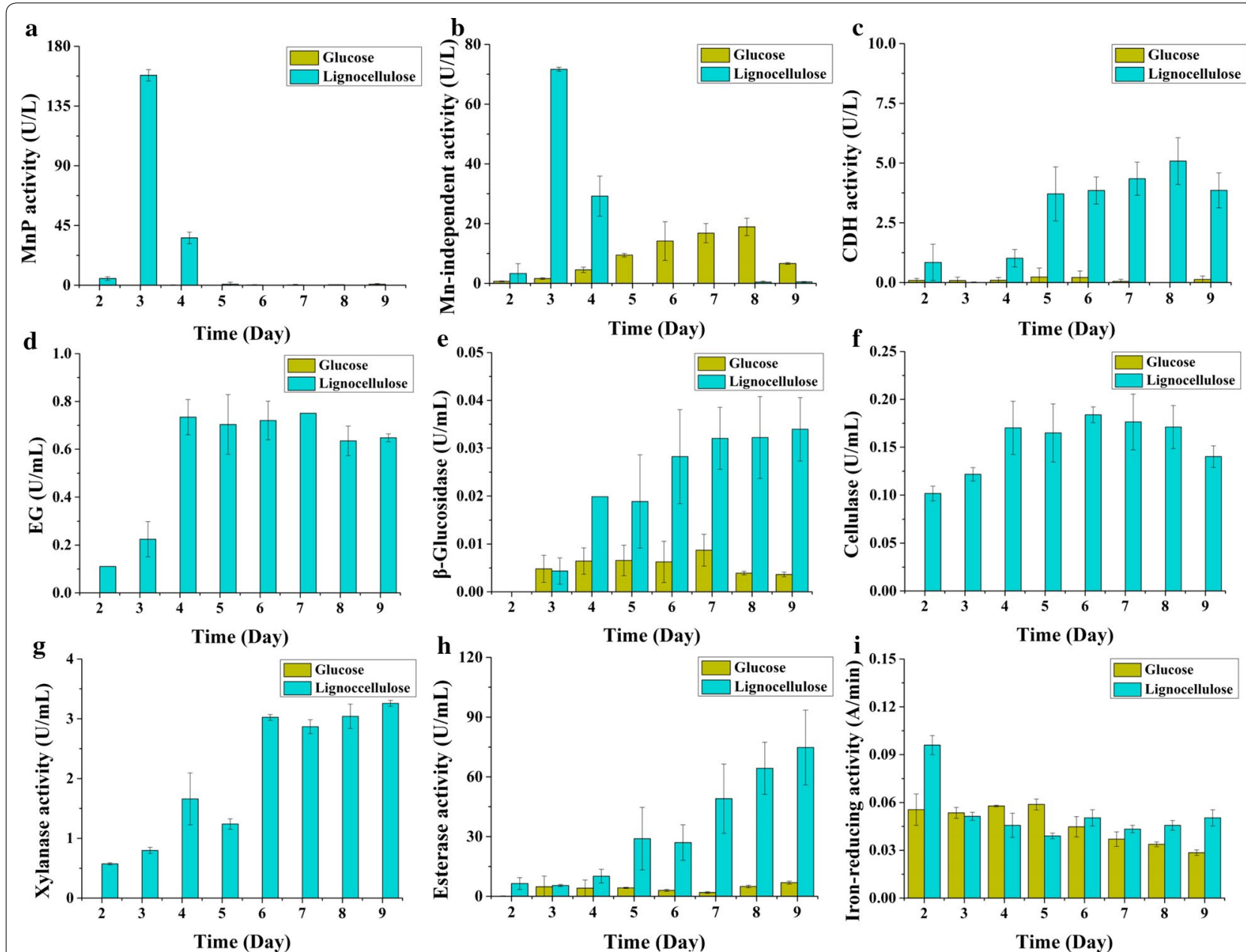

Fig. 2 Time-course biochemical analyses of the lignocellulose-degrading enzyme activities of I. lacteus CD2 cultured in Kirk's media containing corn stover or glucose as carbon source. a MnP activity; b Mn-independent peroxidase activity; $\mathbf{c}$ CDH activity; $\mathbf{d}$ endoglucanase activity; e $\beta$-glucosidase activity; $\mathbf{f}$ overall cellulase activity; $\mathbf{g}$ xylanase activity; $\mathbf{h}$ feruloyl esterase activity; i iron-reducing activity. MnP manganese peroxidase, $C D H$ cellobiose dehydrogenase, EG endoglucanase 
The activity of $\beta$-glucosidase (BG) grew from low (day 3 and before) to intermediate (days 4-5) and then to high (days 6-9) (Fig. 2e). The overall cellulase and xylanase performance was similar to that of EG (Fig. 2f, g). Expression of feruloyl esterase, an enzyme cleaving the ferulic acid linking heterogenous xylan and lignin [51], was similar to BG with the change of the intermediate stage to days 5-6 (Fig. 2h). Moreover, we also noticed that the iron-reducing activity in lignocellulose medium was highest at the very early stage (day 2) (Fig. 2i), suggesting that hydroxyl radical was involved in lignin modification by I. lacteus CD2 [44].

\section{Temporal changes in expression \\ of lignocellulose-degrading enzymes based on transcriptomic analysis}

Based on the above biochemical results, the total RNAs were extracted from the mycelia of I. lacteus CD2 cultured in media containing either lignocellulose or glucose on day 3 and day 6, respectively, and used for RNA-seq transcriptomic analysis. Corresponding to the temporal expression of ligninolytic enzymes and polysaccharides degrading enzymes, the expression levels of a large number of genes were significantly altered ( $\geq 2$-fold) (Fig. 3a and Additional file 7). Comparing the transcriptome of LC3d (lignocellulose, day 3) with Glu3d (glucose, day 3) and LC6d (lignocellulose, day 6) with LC3d by GO analysis, the differently expressed genes were enriched in oxidoreductases and hydrolases (Fig. 3b, c, Table 2 and Additional file 8). KEGG analysis indicated that glyoxylate and phenylalanine metabolism pathway genes involved in degradation of lignin were enriched at the early stage (Additional file 9).

\section{Enzymatic modification of lignin}

The ligninolytic enzymes and auxiliary metabolism systems involved in lignin degradation responded rapidly to lignocellulose. Among the lignin-degrading peroxidases, all $\mathrm{MnP}$ genes (except MnP7) were highly induced in LC3d but rapidly decreased in LC6d (Fig. 3c), well corresponding to the biochemical analysis. Besides, RT-qPCR of selected genes important for lignocellulose degradation showed similar expression profiles to those of RNA-seq data (Additional file 10). In comparison, no up-regulation was observed for DyP genes in LC3d (versus Glu3d) or LC6d (versus LC3d). Moreover, the transcript level of one LiP gene (0810.149) was high in LC3d and LC6d, but no enzymatic activity could be detected for LiP. These indicated that enzymatic oxidative degradation of lignin by I. lacteus CD2 was mainly through MnPs rather than DyPs and LiPs at the early stage. As for $\mathrm{H}_{2} \mathrm{O}_{2}$ generating oxidases, two glyoxal oxidase (GLOX) genes largely accumulated in LC3d but then quickly diminished in LC6d. AOX1 was expressed to a comparably high level in LC3d and LC6d (Fig. 3c).

Low molecular weight compounds such as heme, aromatic compounds, and oxalate play important roles in efficient lignin degradation. Five key genes in the heme biosynthesis pathway were up-regulated in LC3d and the interfering siroheme biosynthesis pathway was repressed (Additional file 4), indicating that heme production was favored under lignocellulosic conditions. Besides, upregulation of gene encoding phenylalanine ammonia lyase improved the production of VA, which could significantly enhance the synthesis of MnP produced by $I$. lacteus CD2 [52]. Five transcripts for glyoxylate dehydrogenase and oxaloacetase and three transcripts for oxalate oxidase and oxalate decarboxylase were up-regulated and down-regulated in LC3d, indicating that the synthesis and degradation of oxalate were promoted and inhibited, respectively (Table 1 and Additional file 5). Furthermore, three CYP53 P450s, which were implicated in the intracellular metabolism of low molecular weight lignin and its decomposed fragments [53], were significantly upregulated in LC3d.

\section{Plant cell wall polysaccharides degradation}

For cellulose degradation, one GH6 cellobiohydrolase was induced in LC3d compared to Glu3d by 88 -fold and further increased by 3.7 -fold in LC6d (Table 2). The other cellobiohydrolase was induced in LC3d by 18.7 -fold but decreased by 1.2 -fold in LC6d. However, its transcript abundance was two orders of magnitude lower than the former one (Table 2). Five among the six endoglucanase genes were up-regulated by 3.3-22.4-fold in LC3d, compared with Glu3d, which further increased by 1.4-5.7-fold in LC6d. The rest endoglucanase (0811.630) had its maximal transcription level in LC6d (27.7-fold higher than in Glu3d). The GH3 $\beta$-glucosidase had a comparable transcription level in LC3d to that in Glu3d, but its transcript increased by 2.0 -fold in LC6d, compared with LC3d. In addition, AA9 LPMOs displayed very similar expression patterns: they were induced in LC3d and their transcript level continued to ascend in LC6d (Fig. 3c), suggestive of their involvement in cellulose degradation [54].

For hemicellulose degradation, two and three GH10 xylanases were highest expressed in LC3d and LC6d, respectively. A GH43 enzyme predicted to degrade xylooligosaccharides into xylose was induced by 27.4-fold in LC3d and the expression further increased by 1.9-fold in LC6d. Two GH51 arabinofuranosidases predicted to cleave the arabinose side chain were expressed at the highest levels in LC6d (Table 2). 
$\mathbf{a}$

\section{LC3d vs Glu3d}

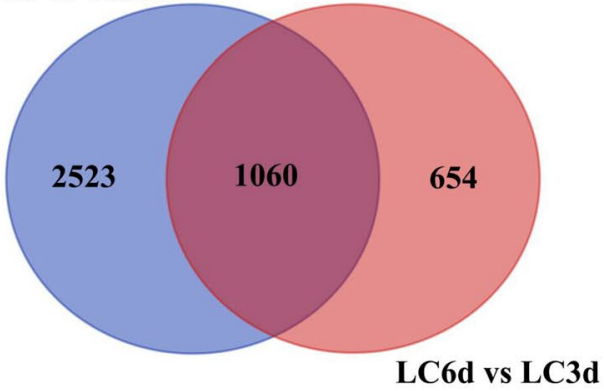

b

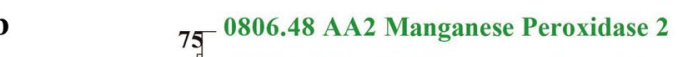

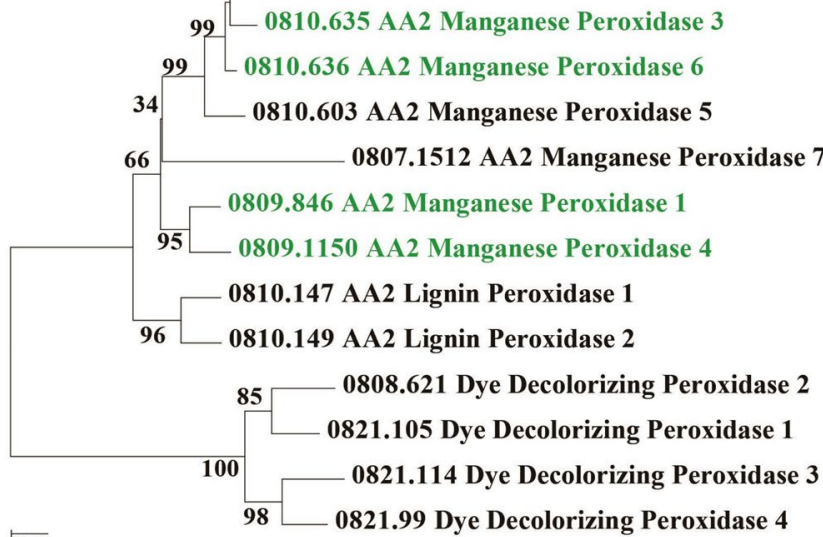

$\overline{0.1}$ 0821.99 Dye Decolorizing Peroxidase 4
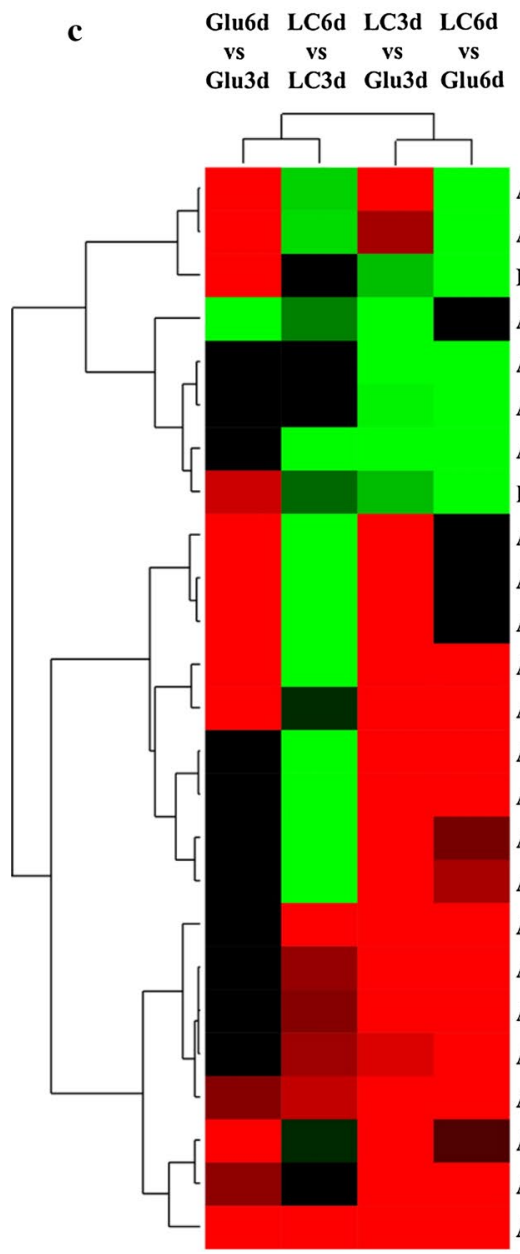

AA2_Lignin Peroxidase 1_0810.147

AA2_Mangnese Peroxidase 5_0810.603

Dye-decolorizing Peroxidase 2_0808.621

AA1_Iron Transport Multicopper Oxidase_0809.825

AA3_Choline Dehydrogenase_0806.638

AA3_Alcohol Oxidase 2_0807.1427

AA3_Choline Dehydrogenase_0809.1069

Dye-decolorizing Peroxidase 1_0821.105

AA2_Manganese Peroxidase 2_0806.48

AA2_Manganese Peroxidase 3_0810.635

AA2_Manganese Peroxidase 6_0810.636

AA2_Lignin Peroxidase 2_0810.149

AA3_Alcohol Oxidase 1_0808.462

AA2_Manganese Peroxidase 1_0809.846

AA5_Glyoxal Oxidase 1_0807.1532

AA2_Manganese Peroxidase 4_0809.1150

AA5_Glyoxal Oxidase 2_0807.1533

AA9_Lytic Polysaccharide Monooxygenase 10_0809.77

AA8_Cellobiose Dehydrogenase_0811.251

AA9_Lytic Polysaccharide Monooxygenase 8_0808.957

AA9_Lytic Polysaccharide Monooxygenase 11_0809.109

AA9_Lytic Polysaccharide Monooxygenase 14_0811.374

AA5_Copper Radical Oxidase 1_0806.696

AA9_Lytic Polysaccharide Monooxygenase 15_0821.14

AA9_Lytic Polysaccharide Monooxygenase 16_0925.1198

\begin{tabular}{|c|c|c|c|}
\hline \multicolumn{4}{|c|}{ FPKM } \\
\hline Glu3d & Glu6d & LC3d & LC6d \\
\hline 5.41 & 699 & 33.3 & 5.98 \\
\hline 6.03 & 587 & 14.7 & 2.46 \\
\hline 26.5 & 1236 & 3.50 & 3.17 \\
\hline 131 & 5.12 & 9.88 & 3.45 \\
\hline 285 & 169 & 7.06 & 5.70 \\
\hline 127 & 138 & 11.1 & 10.7 \\
\hline 1962 & 2393 & 107 & 8.97 \\
\hline 134 & 689 & 18.3 & 7.90 \\
\hline 5.26 & 72 & 9242 & 494 \\
\hline 7.37 & 79.2 & 9373 & 120 \\
\hline 10.9 & 291 & 35529 & 175 \\
\hline 4.47 & 61.2 & 7521 & 784 \\
\hline 5.55 & 115 & 11045 & 7863 \\
\hline 8.65 & 16.6 & 34252 & 919 \\
\hline 1.70 & 2.00 & 4693 & 89.6 \\
\hline 1.00 & 2.07 & 184 & 3.80 \\
\hline 5.60 & 11.3 & 4254 & 30.7 \\
\hline 3.18 & 1.40 & 111 & 1014 \\
\hline 5.54 & 3.81 & 42.9 & 150 \\
\hline 6.73 & 7.84 & 61.0 & 184 \\
\hline 20.0 & 7.97 & 78.2 & 287 \\
\hline 1.78 & 5.21 & 29.8 & 151 \\
\hline 39.7 & 497 & 883 & 651 \\
\hline 31.1 & 98.2 & 383 & 546 \\
\hline 1.34 & 54.6 & 7.99 & 538 \\
\hline
\end{tabular}

Fig. 3 Different expression profiles of ligninolytic enzyme genes. a Venn diagram showing differentially expressed genes by comparing LC3d versus Glu3d (Blue) and LC6d versus LC3d (Red). The numbers of gene with transcript levels changing $\geq 2$-fold were shown. LC3d: lignocellulose, day 3; LC6d: lignocellulose, day 6; Glu3d: glucose, day 3; Glu6d: glucose, day 6. b Phylogenetic analysis of the class II peroxidases and DyPs identified from the genome of I. lacteus CD2. The five MnP genes up-regulated in lignocellulose culture (day 3) were highlighted in green. $\mathbf{c}$ Gene expression profiles for the ligninolytic enzymes associated with lignin modification under the four culturing conditions 
Table 2 Genes and their transcription levels relating to plant cell wall polysaccharides degradation under different culture conditions in I. lacteus CD2

\begin{tabular}{|c|c|c|c|c|c|c|c|c|}
\hline \multirow[t]{2}{*}{ Substrate preference } & \multirow[t]{2}{*}{ Family } & \multirow[t]{2}{*}{ Putative function } & \multirow[t]{2}{*}{ SignalP } & \multirow[t]{2}{*}{ Gene } & \multicolumn{4}{|l|}{ FPKM } \\
\hline & & & & & Glu3d & Glu6d & LC3d & LC6d \\
\hline \multirow[t]{9}{*}{ Cellulose } & $\mathrm{GH} 3$ & Beta-glucosidase & Yes & 0931.133 & 53.1 & 61.6 & 48.1 & 107 \\
\hline & GH5 & Endoglucanase & Yes & 0808.758 & 5.53 & 8.30 & 24.5 & 33.5 \\
\hline & & & Yes & 0816.65 & 5.53 & 5.32 & 27.0 & 74.1 \\
\hline & $\mathrm{GH} 6$ & Cellobiohydrolase & Yes & 0824.208 & 38.6 & 31.0 & 3409 & 12,641 \\
\hline & $\mathrm{GH} 7$ & Cellobiohydrolase & Yes & 0809.465 & 9.97 & 2.37 & 186 & 102 \\
\hline & & Endoglucanase & Yes & 0818.184 & 4.72 & 4.38 & 15.7 & 63.4 \\
\hline & $\mathrm{GH} 12$ & Endoglucanase & Yes & 0811.630 & 2.44 & 1.96 & 2.90 & 67.5 \\
\hline & $\mathrm{GH} 44$ & Endoglucanase & Yes & 0811.593 & 5.89 & 6.94 & 23.1 & 132 \\
\hline & $\mathrm{GH} 45$ & Endoglucanase & Yes & 0810.565 & 2.58 & 2.53 & 57.8 & 82.1 \\
\hline \multirow[t]{8}{*}{ Hemicellulose } & $\mathrm{GH} 10$ & Xylanase & Yes & 0808.183 & 1.24 & 1.70 & 48.1 & 194 \\
\hline & & & Yes & 0808.184 & 0.48 & 1.97 & 2275 & 547 \\
\hline & & & Yes & 0808.185 & 37.5 & 24.4 & 482 & 14.7 \\
\hline & & & Yes & 0809.107 & 0.60 & 0.42 & 40.0 & 643 \\
\hline & & & Yes & 0925.1205 & 6.58 & 5.08 & 12.8 & 67.7 \\
\hline & $\mathrm{GH} 43$ & Xylosidase/arabinosidase & No & 0925.205 & 4.23 & 2.63 & 116 & 217 \\
\hline & GH51 & a-L-arabinofuranosidase & Yes & 0806.422 & 13.5 & 9.07 & 6.14 & 296 \\
\hline & & & Yes & 0808.962 & 1.66 & 1.69 & 14.3 & 25.2 \\
\hline
\end{tabular}

\section{Free-radical generation}

In addition to enzymatic oxidation of lignin, hydroxyl radical produced from Fenton reaction and carboxylatederived radicals generated from $\mathrm{Mn}^{3+}$ /oxalate would also be involved in lignin modification by I. lacteus CD2. The genes involved in iron transportation and reduction and $\mathrm{H}_{2} \mathrm{O}_{2}$ production responsible for generating hydroxyl radical displayed a complex regulation pattern. For example, the transcripts of $\mathrm{CDH}$, glycopeptide, and quinate permease responsible for extracellular reduction of $\mathrm{Fe}^{3+}$ accumulated in LC3d. In contrast, the transcript levels of siderophore iron transporter and permease Ftr1 were lowest in LC3d (Table 1). Apart from hydroxyl radical, carboxylate-derived radicals were another important kind of free-radical system. Organic acids such as oxalate can stimulate oxidation of non-phenolic lignin by MnPs from I. lacteus CD2 [55]. The transcripts for MnPs and oxalate-producing enzymes were most abundant in LC3d (Fig. 3c and Additional file 5).

\section{Discussion}

Previous to our study, there was only one brief report on the genome sequence of an I. lacteus strain F17 [21]. In this study, we found that the genome of I. lacteus CD2 is $43.16 \mathrm{Mb}$, similar to but slightly smaller than that of formerly sequenced I. lacteus F17 (44.36 Mb). Despite this similarity, however, I. lacteus CD2 encodes higher numbers of plant cell wall polysaccharide-degrading enzymes, with $182 \mathrm{GHs}$ compared to $161 \mathrm{GHs}$ in I. lacteus F17 [21]. In addition, I. lacteus CD2 does not have a laccase, but have $7 \mathrm{MnPs}, 2 \mathrm{LiPs}$, and 4 DyPs, while I. lacteus F17 bears one laccase, one LiP, 13 MnPs but no DyP. The study of strain F17 focused on detoxification of synthetic dyes but not in pretreatment of lignocellulose [56, 57]. Therefore, it is not known at this time whether the difference in the numbers and amino acid sequences of encoding enzymes by the two strains would impact their efficiency in lignocellulose degradation. The 18S rRNA phylogenetic analysis suggested that I. lacteus F17 is closest to C. subvermispora, a selective lignin degrader [21]. Taxonomy based on 18S rRNA gene showed a limitation for certain order level [58-60], while the phylogenomic approach could improve phylogenetic accuracy. Our comparative analysis at a phylogenomic level revealed that $I$. lacteus $\mathrm{CD} 2$ is very close to the selective white rot fungus $P$. carnosa.

The sequenced and annotated genome of I. lacteus CD2 presented here provides an excellent platform for subsequent biochemical and transcriptomic analyses of this fungus grown on lignocellulose. The carbon source used for submerged shake flask fermentation in this study was ball-milled corn stover, whose natural physical structure has been disrupted to some extent. However, the expression pattern of extracellular lignocellulosedegrading enzymes was still very similar to that of this fungus grown in solid-state fermentation (SSF) on corn 
stover [19]. Both the current submerged fermentation and previous SSF revealed roughly identical expression patterns, with high lignin-degrading enzymes appearing at the early stage and high expression of cellulase at the late stage.

The large accumulation of $\mathrm{MnP}$ transcripts and enzymatic activities at the early stage highlights their importance involved in lignin degradation. Indeed, two recombinant MnPs from I. lacteus CD2 exhibited $\mathrm{Mn}^{2+}$-dependent oxidation ability for phenolic lignin model compounds [55]. These facts are consistent with the finding that supplementing with $\mathrm{Mn}^{2+}$ greatly improved the pretreatment efficiency of corn stover by I. lacteus CD2 [61]. MnPs are enzymes that can directly attack phenolic lignin but not non-phenolic lignin compounds [62]. However, phenolic lignin represents only a minor part of lignin $(\sim 10 \%)$, the more recalcitrant and high redox-potential non-phenolic lignin constitutes the major part. The apparent paradox could be explained by our recent discovery that certain carboxylates such as malonate, and more importantly those produced in the life cycle of the fungus such as oxalate, can be used by the above-mentioned MnPs from I. lacteus to generate free radicals, which can mediate oxidation of non-phenolic lignin compounds [55]. As a supporting evidence, the genes controlling oxalate production and metabolism experienced regulation favoring accumulation of oxalate on LC3d (Additional file 5). The oxalate concentration was in the range of $0.11 \sim 0.13 \mathrm{mg} / \mathrm{ml}(1.22 \sim 1.44 \mathrm{mM})$ from LC3d to LC9d, which can be used by MnPs for oxidation of non-phenolic lignin. Since there was no detectable LiP and DyP activity during cultivation, MnPs, in combination with GLOX and AOX, appeared to be main components of the extracellular lignin-degrading enzyme system for I. lacteus CD2 growth on corn stover.

Similar to solid-state biological pretreatment of corn stover by I. lacteus CD2 [63], $\mathrm{Fe}^{3+}$-reducing activity was detected during all the culture periods. It was noteworthy that the peak of $\mathrm{Fe}^{3+}$-reducing activity appeared at the very early stage (day 2) even before the MnPs (day 3). $\mathrm{Fe}^{2+}$ can react with $\mathrm{H}_{2} \mathrm{O}_{2}$ via Fenton reaction and produce hydroxyl radical, attacking both lignin and plant cell wall polysaccharides [44]. Hydroxyl radical demethoxylated aromatic groups in lignin and introduces hydroxyl groups in non-phenolic lignin [26]. This process is important, which results into cleavages of lignocellulose barrier, thus facilitating subsequent penetration of MnPs and glycoside hydrolases [64]. Interestingly, the $\mathrm{Fe}^{3+}$-reducing activity rapidly decreased to normal state from day 3 to day 9 in lignocellulose medium, which was at a level similar to that in glucose medium (Fig. 2i). However, despite the down-regulated $\mathrm{Fe}^{3+}$-reducing activity during this period, degradation of lignocellulose by free radical generated through reaction of $\mathrm{Fe}^{3+}$ with $\mathrm{H}_{2} \mathrm{O}_{2}$ cannot be excluded. At the early stage (LC3d), a range of AA3 and AA5 auxiliary enzymes were highly enriched (Table 1), providing $\mathrm{H}_{2} \mathrm{O}_{2}$ for both $\mathrm{MnPs}$ and $\mathrm{Fe}^{2+}$. At the late stage (LC6d), part of AA3 and AA5 enzymes was still highly expressed (e.g. 0806.696 and 0808.462, Fig. 3c). At this stage, cellulase was highly expressed, hydrolyzing cellulose into cellobiose and cellooligosaccharides. These sugars serve as substrates of $\mathrm{CDH}$, which was also highly induced in LC6d (Fig. 3c), and could generate sufficient amounts of $\mathrm{H}_{2} \mathrm{O}_{2}$ for $\mathrm{Fe}^{2+}$. As another important source of hydroxyl radicals [65], the transcript of glycopeptide was highly expressed on LC3d and LC6d, as well.

In accordance with biochemical analysis, the transcriptomic study revealed that the transcripts for $\mathrm{MnP}$ isoenzymes were highly expressed at the early stage, but decreased over time in lignocellulose culture. The transcripts for cellulase and hemicellulase gradually increased with the time going on. The special expression pattern of genes encoding lignocellulose-degrading enzymes was similar to that of the selective ligninolytic fungus $C$. subvermispora during growth on aspen wood [13]. However, the transcriptomic and biochemical analyses also revealed significant difference in lignin degradation between I. lacteus CD2 and C. subvermispora. For lignin decomposition, I. lacteus $\mathrm{CD} 2$ mainly uses MnPs which are assisted by the $\mathrm{H}_{2} \mathrm{O}_{2}$ producers GLOX and AOX, while C. subvermispora utilizes laccases and MnPs with AAO. Moreover, the substrate scope of MnPs from I. lacteus $\mathrm{CD} 2$ expands to the predominant non-phenolic lignin with the aid of oxalate [55], while peroxyl radical, generated through interplay of fatty acid desaturases and $\mathrm{MnPs}$, is implicated to be responsible for cleavage of non-phenolic lignin in C. subvermispora [38]. The expression of important genes involved in lignocellulose degradation is also different between I. lacteus CD2 and another model white rot fungus $P$. chrysosporium. In $I$. lacteus $\mathrm{CD} 2$, the gene encoding glycopeptide related to $\mathrm{Fe}^{3+}$ reduction was highly expressed on LC3d and LC6d. The $\mathrm{CDH}$ gene involved in $\mathrm{Fe}^{3+}$ reduction was also upregulated on LC6d compared to LC3d (Table 1), which may affect the rate of Fenton reaction. In contrast, the transcript of $\mathrm{CDH}$ remains abundant, while those of glycopeptides are negligible in $P$. chrysosporium during all the culture periods [12].

Taken together, based on biochemical, genomic, and transcriptomic analyses, we could propose a model for lignocellulose degradation by I. lacteus CD2 in this submerged fermentation. At the very early stage (day 2 and before), when MnPs are to be expressed, I. lacteus $\mathrm{CD} 2$ up-regulates the $\mathrm{Fe}^{3+}$-reducing power. $\mathrm{Fe}^{2+}$ reacts with low level of $\mathrm{H}_{2} \mathrm{O}_{2}$ to produce hydroxyl radical for an initial attack and breakage of interlinking 
lignocellulose network. At the early stage (days 3-4), MnPs are predominantly expressed and directly oxidize phenolic lignin compound. With assistance of mediators such as oxalate, non-phenolic lignin components are also oxidized by MnPs. Cellulase and xylanase are beginning to accumulate, but still not to the highest level. At the late stage (days 5, 6, and after), MnPs disappear, but part of enzymes responsible for $\mathrm{H}_{2} \mathrm{O}_{2}$ generation are highly expressed, which allow production of $\mathrm{H}_{2} \mathrm{O}_{2}$ and subsequent hydroxyl radical. Cellulase and xylanase are abundantly expressed at this stage, decomposing cellulose and hemicellulose at the maximal speed. In a model described previously [66], the lack of enzymes (such as $\beta$-glucosidase and $\beta$-xylosidase) cleaving oligosaccharides into simple sugars is key for high saccharification efficiency of grass biomass after I. lacteus pretreatment. Indeed, our findings support this hypothesis, because in LC3d, the transcription of $\beta$-glucosidase and the enzymatic activity were very low. With this in mind, our findings corroborate the idea that selective expression of lignin-degrading enzymes at the early stage could be an additional key factor for high saccharification efficiency of lignocellulose after I. lacteus CD2 biopretreatment. Selective removal of lignin at the early stage exposes cellulose ready for enzymatic hydrolysis, while low expression of extracellular $\beta$-glucosidase keeps cellulose in long-chain, non-fermentable form. These two characters enable $I$. lacteus a suitable white rot for pretreating grass feedstock for biofuel production with high efficiency. We also notice that the regulation of $\mathrm{Fe}^{3+}$-reducing activity, as well as hydroxyl radical generation, is complex. Since high concentrations of free radicals and $\mathrm{H}_{2} \mathrm{O}_{2}$ are harmful for both enzymes and microbial hosts, this implies that, any attempts to harness the power of free radicals for formulating novel, robust lignocellulose-degrading enzyme cocktails should be delicately designed.

\section{Conclusions}

In this study, we sought to decipher the molecular mechanism underlying efficient lignocellulose degradation by I. lacteus CD2. The genome annotation indicated that $I$. lacteus CD2 has a full array of enzymes for lignin, cellulose, and hemicellulose degradation. Both biochemical and transcriptomic analyses indicated that the fungus employed a selective strategy for degradation of lignocellulose in this submerged fermentation, a phenomenon reminiscent to that in solid-state fermentation on corn stover. This strategy, in combination with low extracellular glycosidase activity, forms the basis for its high efficiency in biological pretreatment of corn stover for saccharification.

\section{Methods}

\section{Strain, media and culture conditions}

Irpex lacteus CD2 was isolated from Shennongjia Nature Reserve (Hubei, China) and preserved in the Institute of Environment and Resource Microbiology, Huazhong University of Science and Technology, Wuhan, China. I. lacteus $\mathrm{CD} 2$ was maintained at $4{ }^{\circ} \mathrm{C}$ on potato-dextrose agar plates. The inoculum was pre-cultured in potato-dextrose broth for 7 days at $28{ }^{\circ} \mathrm{C}$, transferred into the modified Kirk's medium as $10 \%(\mathrm{v} / \mathrm{v})$ inoculum, and shaken at $150 \mathrm{rpm}$. The Kirk's medium contained: ball-milled corn stover (or glucose) as carbon source, $10 \mathrm{~g} / \mathrm{L}$; ammonium tartrate, $0.2 \mathrm{~g} / \mathrm{L} ; \mathrm{KH}_{2} \mathrm{PO}_{4}$, $2 \mathrm{~g} / \mathrm{L} ; \mathrm{MgSO}_{4} \cdot 7 \mathrm{H}_{2} \mathrm{O}, 0.71 \mathrm{~g} / \mathrm{L} ; \mathrm{CaCl}_{2}, 0.1 \mathrm{~g} / \mathrm{L}$; and $70 \mathrm{~mL}$ trace element solution. The trace element solution contains $\mathrm{NaCl}, 1 \mathrm{~g} / \mathrm{L} ; \mathrm{CoCl}_{2} \cdot 6 \mathrm{H}_{2} \mathrm{O}, 0.184 \mathrm{~g} / \mathrm{L} ; \mathrm{FeSO}_{4} \cdot 7 \mathrm{H}_{2} \mathrm{O}$, $0.1 \mathrm{~g} / \mathrm{L} ; \mathrm{ZnSO}_{4} \cdot 7 \mathrm{H}_{2} \mathrm{O}, 0.1 \mathrm{~g} / \mathrm{L} ; \mathrm{CuSO}_{4}, 0.1 \mathrm{~g} / \mathrm{L} ; \mathrm{H}_{3} \mathrm{BO}_{3}$, $0.01 \mathrm{~g} / \mathrm{L} ; \mathrm{Na}_{2} \mathrm{MoO}_{4} \cdot 2 \mathrm{H}_{2} \mathrm{O}, 0.01 \mathrm{~g} / \mathrm{L} ; \mathrm{KAl}\left(\mathrm{SO}_{4}\right)_{2} \cdot 12 \mathrm{H}_{2} \mathrm{O}$, $0.01 \mathrm{~g} / \mathrm{L} ;$ and nitrilotriacetic acid, $1.5 \mathrm{~g} / \mathrm{L}$ [13].

\section{Genome sequencing and assembly}

The genomic DNA of I. lacteus CD2 was extracted using an improved cetyltrimethylammonium bromide (CTAB) method [67] from the mycelia, which was sequenced using both the Illumina HiSeq 2000 and PacBio RS platforms. For second-generation sequencing technology on HiSeq 2000 platform, the genomic DNA was randomly fragmented using the Covaris S2 ultrasonic system. For paired-end 100-bp sequencing, one 500-bp library was prepared using the NEBNext ultra DNA library Prep Kit for Illumina according to the manufacturer's instructions. The Illumina sequencing yielded $5.2 \mathrm{G}$ clean data in 51,969,572 quality-filtered paired-end reads. For third generation sequencing on the PacBio RS II platform, the genomic DNA was sheared using ultrasonics and one 10-kb SMRT-bell library was constructed according to the Pacific Biosciences SMRT Sequencing instruction manual. The PacBio sequencing yielded $4.5 \mathrm{G}$ clean data in 396,897 quality-filtered reads from five SMRT cells. The LSC software was first used for PacBio reads error correction with all the Hiseq 2000 short reads. The corrected PacBio RS data were assembled with hierarchical genome assembly process using default parameters [68].

\section{Gene identification and annotation}

To identify gene models in the I. lacteus CD2 genome, the genome assembly was first analyzed for simple sequence repeat using the MISA software and masked by RepeatMasker, RepeatProteinMasker, and TRF using the RepBase library. Using the repeat-masked assembly, gene models were predicted using de novo prediction tools (Augustus, GeneMark-ES, and Snap) and homology prediction tool (GeneWise) with default parameters. The 
de novo and homology-based gene models were merged to form a comprehensive and non-redundant reference gene models by EVM [69]. The predicted gene models were functionally annotated using BLASTp against the National Center for Biotechnology Information nonredundant database, SwissProt, and TrEMBL and were also mapped to functional terms including $\mathrm{KOG}, \mathrm{GO}$, and KEGG pathways. The tRNAscan-SE software was used to detect tRNA regions and its secondary structures [70]. The rRNAs were identified with the hidden Markov models using the RNAmmer software [71].

\section{Phylogenomic analysis}

The genome sequences of I. lacteus CD2 and eight other Polyporales fungi including B. adusta, C. subvermispora, D. squalens, Ganoderma sp., P. carnosa, P. chrysosporium, P. placenta, and T. versicolor were collected, and a phylogenetic tree was constructed by using the MAFFT and FastTree software based on the deduced amino acid sequences of orthologous genes $[72,73]$.

\section{CAZymes and auxiliary enzymes}

All I. lacteus CD2 protein models were subjected to a procedure combing BLAST and HMMer3 searches against sequence libraries and HMM profiles derived from the families of GHs, PLs, CEs, GTs, auxiliary activities (AAs), and CBMs featured in the CAZy database. The Class II peroxidases and DyPs were further confirmed by BLAST search against the PeroxiBase database [74].

\section{Composition analysis}

For compositional analysis, the non-treated corn stover and that treated by I. lacteus CD2 (on days 3, 6, and 9) were collected by centrifugation and then dried at $60{ }^{\circ} \mathrm{C}$ for 3 days. Lignin, cellulose, and hemicellulose components of corn stover were determined according to the procedure described by the National Renewable Energy Laboratory [75]. For each sample, the compositional analysis was performed in triplicate. The degradation percentage of lignin, cellulose, and hemicellulose was calculated using the following formula:
0.1- $\mathrm{mM} \mathrm{H}_{2} \mathrm{O}_{2}$. One unit of MnP activity was defined as the amount of enzyme that oxidized $1 \mu \mathrm{mol}$ of $\mathrm{Mn}^{2+}$ per min at $25{ }^{\circ} \mathrm{C}$ [52]. The $\mathrm{Mn}^{2+}$-independent activity was measured by monitoring the oxidation of 1-mM ABTS $\left(\varepsilon_{420}=36,000 / \mathrm{M} / \mathrm{cm}\right)$ at $420 \mathrm{~nm}$, in a buffer containing $50-\mathrm{mM} \mathrm{pH} 5.0$ malonate and 0.1- $\mathrm{mM} \mathrm{H}_{2} \mathrm{O}_{2}$. One unit of $\mathrm{Mn}^{2+}$-independent activity was defined as the amount of enzyme that oxidized $1 \mu \mathrm{mol}$ of ABTS per min at $25^{\circ} \mathrm{C}$ [55]. Iron-reducing activity was determined by forming $\mathrm{Fe}^{2+}$-ferrozine complex in the $50-\mathrm{mM} \mathrm{pH} 4.8$ acetate buffer containing $0.3-\mathrm{mM} \mathrm{FeCl}_{3}$ and $4-\mathrm{mM}$ ferrozine. One unit of iron-reducing activity was defined as the rate of absorbance increase at $562 \mathrm{~nm} / \mathrm{min}$. The $\mathrm{CDH}$ activity was determined by oxidation of 0.3-mM 2,6-dichloroindophenol sodium salt (DCPIP, $\varepsilon_{520}=68,000 / \mathrm{M} / \mathrm{cm}$ ) at $520 \mathrm{~nm}$ in the presence of $30-\mathrm{mM}$ lactose in the $50-\mathrm{mM}$ $\mathrm{pH} 4.8$ acetate buffer. One unit of $\mathrm{CDH}$ activity was defined as the amount of enzyme that oxidized $1 \mu \mathrm{mol}$ of DCPIP per min at $25{ }^{\circ} \mathrm{C}$ [76]. For cellulose- and hemicellulose-degrading enzymes, the overall cellulase activity, EG, BG, and xylanase activities were determined according to the method described by $\mathrm{Xu}$ et al. [63]. The esterase activity was determined using 1-mM $p$-nitrophenyl butyrate $\left(\varepsilon_{348}=8321 / \mathrm{M} / \mathrm{cm}\right)$ at $348 \mathrm{~nm}$ in the $50-\mathrm{mM} \mathrm{pH}$ 6.0 sodium phosphate buffer. One unit of esterase activity was defined as the amount of enzyme that released $1 \mu \mathrm{mol}$ of $p$-nitrophenol per min at $25^{\circ} \mathrm{C}$ [77].

\section{Transcriptome sequencing}

Irpex lacteus CD2 was grown in the modified Kirk's medium containing corn stover or glucose as carbon source. The total RNA was extracted from mycelia on days 3 and 6 using the TRIZOL reagent (Invitrogen, Waltham, MA) according to the manufacturer's instructions. The total RNA was sent to Annoroad Genomics (Beijing, China) for sample preparation and sequencing. All samples were in duplicate. The cDNA library was synthesized and prepared for sequencing using the Illumina mRNA-Seq Sample Prep Kit (San Diego, CA). Briefly, first, the poly(A) containing mRNA was purified from total RNA with poly(T) oligo-attached magnetic beads and fragmented. Next, the cleaved RNA fragments were reversely transcribed into first-strand cDNA using

Degradation rate $(\%)=\left(1-\frac{\text { lignin(cellulose, or hemicellulose) content in treated corn stover } \times \text { final weight of corn stover after treatement }}{\text { lignin }(\text { cellulose } \text { or hemicellulose) content in raw corn stover } \times \text { initial weight of raw corn stover }}\right) \times 100$.

\section{Enzymatic assays}

For lignin-degrading enzymes, $\mathrm{MnP}$ activity was measured by monitoring the oxidation of $1-\mathrm{mM} \mathrm{MnSO}_{4}$ $\left(\varepsilon_{270}=11,590 / \mathrm{M} / \mathrm{cm}\right)$ at $270 \mathrm{~nm}$, in a buffer containing $50-\mathrm{mM} \mathrm{pH} 5.0$ malonate, 1-mM $\mathrm{MnSO}_{4}$, and reverse transcriptase and random primers, followed by second-strand cDNA synthesis. Then, the DNA fragments were further subjected to end repair, addition of "A" bases, and adapters' ligation. Finally, cDNA templates were purified and enriched by PCR amplification. 
The cDNA libraries were run in independent lanes and paired-end sequences of $125 \mathrm{bp}$ were obtained with at least 4-Gb clean data for each sample using the Illumina Hiseq 2500.

\section{Differential expression analysis}

The raw reads were trimmed and filtered using Trimmomatic software to remove adapters and low-quality bases [78]. Then, clean reads were assembled into transcripts using TopHat and Cufflinks with the I. lacteus CD2 genome as a Ref. [79]. All sequences of transcripts were extracted from reference sequence using gffread from cufflinks pipeline. The gene expression levels were conducted using the fragments per kilobase of exon per million fragments mapped (FPKM) method [80], and read counts were analyzed for differential expression using edgeR [81] with a $p \leq 0.05$ and a false discovery rate $(\mathrm{FDR}) \leq 0.01$.

Reverse transcription-quantitative PCR (RT-qPCR) of selected ligninolytic genes was used for confirmation of RNA-seq data, which was conducted using TransStart Green RCR SuperMix (TransGen) with gene-specific primers (as shown in Additional file 11). The reaction conditions were set as follows: $95{ }^{\circ} \mathrm{C} 10 \mathrm{~min}$ for initial denaturation; 40 cycles of $94{ }^{\circ} \mathrm{C}$ for $10 \mathrm{~s}, 66{ }^{\circ} \mathrm{C}$ for $20 \mathrm{~s}$, and $72{ }^{\circ} \mathrm{C}$ for $20 \mathrm{~s}$. The relative fold of change in selected ligninolytic genes was analyzed using the $2^{-\Delta \Delta C T}$ method with the glycerol 3-phosphate dehydrogenase-normalized $\mathrm{Ct}$ values [82]. The samples from LC6d were compared to those from LC3d.

\section{Additional files}

Additional file 1. Summary of I. lacteus CD2 annotations.

Additional file 2. Top 50 PFAM domains in I. lacteus CD2 genome.

Additional file 3. Oxidoreductive enzymes involved in lignocellulose degradation in I. lacteus CD2 and selected Polyporales genomes.

Additional file 4. Predicted heme biosynthesis pathway and its regulation in I. lacteus CD2.

Additional file 5. TCA cycle, GLOX cycle, and predicted oxalate metabolism in I. lacteus CD2.

Additional file 6. Distribution of the genes encoding glycoside hydrolases and enzymes with auxiliary activities on the 10 largest contigs of $I$. lacteus CD2 genome.

Additional file 7. Differential expression analysis in comparisons of LC3d versus Glu3d and LC6d versus LC3d.

Additional file 8. GO enrichment analysis of differently expressed genes in comparisons of LC3d versus Glu3d (a), LC6d versus LC3d (b).

Additional file 9. KEGG enrichment analysis of differently expressed genes in comparisons of LC3d versus Glu3d (a), LC6d versus LC3d (b).

Additional file 10. Verifying the differential expression as revealed by RNA-seq for selected lignocellulose-degrading genes by RT-qPCR.

Additional file 11. Primers used for RT-qPCR.

\section{Abbreviations}

DyPs: dye-decolorizing peroxidases; $\mathrm{H}_{2} \mathrm{O}_{2}$ : hydrogen peroxide; CAZymes: carbohydrate active enzymes; P450s: cytochrome P450 monooxygenases; MFS: major facilitator superfamily; GMC: glucose methanol choline; CDH: cellobiose dehydrogenase; AAO: aryl alcohol oxidases; AOX: alcohol oxidases; POX: pyranose-2-oxidase; VA: veratryl alcohol; GHs: glycoside hydrolases; GTs: glycosyltransferases; PLs: polysaccharide lyases; CEs: carbohydrate esterases; LPMOs: lytic polysaccharide monooxygenases; CBM1: carbohydrate-binding module 1; MnPs: manganese peroxidases; MIP: manganese-independent peroxidase; LiP: lignin peroxidase; EG: endoglucanase; BG: $\beta$-glucosidase; GLOX: glyoxal oxidase; SSF: solid-state fermentation; CTAB: cetyltrimethylammonium bromide; AAs: auxiliary activities; DCPIP: 2,6-dichloroindophenol sodium salt; FPKM: fragments per kilobase of exon per million fragments mapped; FDR: false discovery rate; RT-qPCR: reverse transcription quantitative.

\section{Authors' contributions}

$X Q, X S, B Y$, and $F M$ designed research; $X Q$ and $X S$ performed research; $X Q$, $X S, H L$, and RM analyzed the data; $X S$ and $B Y$ contributed new reagents and analytic tools; XQ, XS, HL, RM, BY, and FM wrote the paper. All authors read and approved the final manuscript.

\section{Competing interests}

The authors declare that they have no competing interests.

\section{Availability of data and materials}

All data supporting the conclusions of this article are included within the manuscript and additional files.

\section{Consent for publication}

All authors provide their consent for publication of their manuscript in Biotechnology for Biofuels.

\section{Ethics approval and consent to participate Not applicable.}

\section{Funding}

This research was supported by the National Natural Science Foundation of China (No. 31570577), the National Key Research and Development Program of China (2016YFD0501409-02), the General Program of National Natural Science Foundation of China (31672458), the National High-Tech Research and Development Program of China (863 Program, No. 2013AA102803), the National Science Fund for Distinguished Young Scholars of China (No. 31225026), the China Modern Agriculture Research System (No. CARS-42), and the Elite Youth Program of Chinese Academy of Agricultural Sciences.

\section{Publisher's Note}

Springer Nature remains neutral with regard to jurisdictional claims in published maps and institutional affiliations.

Received: 26 November 2017 Accepted: 23 February 2018

Published online: 02 March 2018

References

1. Sánchez C. Lignocellulosic residues: biodegradation and bioconversion by fungi. Biotechnol Adv. 2009;27:185-94.

2. Worrall JJ, Anagnost SE, Zabel RA. Comparison of wood decay among diverse lignicolous fungi. Mycologia. 1997;89:199-219.

3. Pandey KK, Pitman AJ. FTIR studies of the changes in wood chemistry following decay by brown-rot and white-rot fungi. Int Biodeterior Biodegradation. 2003;52:151-60.

4. Goodell B. Brown-rot fungal degradation of wood our: evolving view. Wood deterioration and preservation. Washington: American Chemical Society; 2003.

5. Sindhu R, Binod P, Pandey A. Biological pretreatment of lignocellulosic biomass_an overview. Bioresour Technol. 2016;199:76-82. 
6. Ohm RA, Riley R, Salamov A, Min B, Choi I-G, Grigoriev IV. Genomics of wood-degrading fungi. Fungal Genet Biol. 2014;72:82-90.

7. Baldrian P, López-Mondéjar R. Microbial genomics, transcriptomics and proteomics: new discoveries in decomposition research using complementary methods. Appl Microbiol Biotechnol. 2014;98:1531-7.

8. Grigoriev IV, Nikitin R, Haridas S, Kuo A, Ohm R, Otillar R, Riley R, Salamov A, Zhao X, Korzeniewski F, et al. MycoCosm portal: gearing up for 1000 fungal genomes. Nucleic Acids Res. 2014;42:D699-704.

9. Floudas D, Binder M, Riley R, Barry K, Blanchette RA, Henrissat B, Martinez AT, Otillar R, Spatafora JW, Yadav JS, et al. The Paleozoic origin of enzymatic lignin decomposition reconstructed from 31 fungal genomes. Science. 2012:336:1715-9.

10. Vanden Wymelenberg A, Gaskell J, Mozuch M, Splinter BonDurant S, Sabat G, Ralph J, Skyba O, Mansfield SD, Blanchette RA, Grigoriev IV, et al. Significant alteration of gene expression in wood decay fungi Postia placenta and Phanerochaete chrysosporium by plant species. Appl Environ Microbiol. 2011;77:4499-507.

11. Vanden Wymelenberg A, Gaskell J, Mozuch M, Sabat G, Ralph J, Skyba O, Mansfield SD, Blanchette RA, Martinez D, Grigoriev I, et al. Comparative transcriptome and secretome analysis of wood decay fungi Postia placenta and Phanerochaete chrysosporium. Appl Environ Microbiol. 2010;76:3599-610.

12. Korripally P, Hunt CG, Houtman CJ, Jones DC, Kitin PJ, Cullen D, Hammel $K E$. Regulation of gene expression during the onset of ligninolytic oxidation by Phanerochaete chrysosporium on spruce wood. Appl Environ Microbiol. 2015;81:7802-12.

13. Hori C, Gaskell J, Igarashi K, Kersten P, Mozuch M, Samejima M, Cullen D. Temporal alterations in the secretome of the selective ligninolytic fungus Ceriporiopsis subvermispora during growth on aspen wood reveal this organism's strategy for degrading lignocellulose. Appl Environ Microbiol. 2014:80:2062-70.

14. Couturier M, Navarro D, Chevret D, Henrissat B, Piumi F, Ruiz-Dueñas FJ, Martinez AT, Grigoriev IV, Riley R, Lipzen A, et al. Enhanced degradation of softwood versus hardwood by the white-rot fungus Pycnoporus Coccineus. Biotechnol Biofuels. 2015:8:216.

15. Kuuskeri J, Häkkinen M, Laine P, Smolander O-P, Tamene F, Miettinen S, Nousiainen P, Kemell M, Auvinen P, Lundell T. Time-scale dynamics of proteome and transcriptome of the white-rot fungus Phlebia radiata: growth on spruce wood and decay effect on lignocellulose. Biotechnol Biofuels. 2016;9:192.

16. Rytioja J, Hildén K, Di Falco M, Zhou M, Aguilar-Pontes MV, Sietiö O-M, Tsang A, de Vries RP, Mäkelä MR. The molecular response of the white-rot fungus Dichomitus squalens to wood and non-woody biomass as examined by transcriptome and exoproteome analyses. Environ Microbiol. 2017:19:1237-50

17. Martínez AT, Speranza M, Ruiz-Dueñas FJ, Ferreira P, Camarero S, Guillén F, Martínez MJ, Gutiérrez A, del Río JC. Biodegradation of lignocellulosics: microbial, chemical, and enzymatic aspects of the fungal attack of lignin. Int Microbiol. 2005:8:195-204.

18. Blanchettel R, BurnesI T, Eerdmans M, Akhtar M. Evaluating isolates of Phanerochaete chrysosporium and Ceriporiopsis subvermispora for use in biological pulping processes. Holzforschung. 1992;46:109-15.

19. Xu C, Ma F, Zhang X, Chen S. Biological pretreatment of corn stover by Irpex lacteus for enzymatic hydrolysis. J Agric Food Chem. 2010;58:10893-8.

20. García-Torreiro M, López-Abelairas M, Lu-Chau TA, Lema JM. Fungal pretreatment of agricultural residues for bioethanol production. Ind Crops Prod. 2016;89:486-92.

21. Yao MW, Li WM, Duan ZH, Zhang YL, Jia R. Genome sequence of the white-rot fungus Irpex lacteus F17, a type strain of lignin degrader fungus. Stand Genomic Sci. 2017;12:55.

22. Salvachua D, Martinez AT, Tien M, Lopez-Lucendo MF, Garcia F, de los Rios V, Martinez MJ, Prieto A. Differential proteomic analysis of the secretome of Irpex lacteus and other white-rot fungi during wheat straw pretreatment. Biotechnol Biofuels. 2013;6:115.

23. Cheng JJ, Timilsina GR. Status and barriers of advanced biofuel technologies: a review. Renew Energy. 2011;36:3541-9.

24. Suzuki H, MacDonald J, Syed K, Salamov A, Hori C, Aerts A, Henrissat B, Wiebenga A, VanKuyk PA, Barry K, et al. Comparative genomics of the white-rot fungi, Phanerochaete carnosa and P. chrysosporium, to elucidate the genetic basis of the distinct wood types they colonize. BMC Genom. 2012;13:444.

25. Chen S, Xu J, Liu C, Zhu Y, Nelson DR, Zhou S, Li C, Wang L, Guo X, Sun Y, et al. Genome sequence of the model medicinal mushroom Ganoderma lucidum. Nat Commun. 2012:3:913.

26. Ten Have R, Teunissen PJ. Oxidative mechanisms involved in lignin degradation by white-rot fungi. Chem Rev. 2001;101:3397-413.

27. Bugg TDH, Ahmad M, Hardiman EM, Rahmanpour R. Pathways for degradation of lignin in bacteria and fungi. Nat Prod Rep. 2011;28:1883-96.

28. Riley R, Salamov AA, Brown DW, Nagy LG, Floudas D, Held BW, Levasseur A, Lombard V, Morin E, Otillar R, et al. Extensive sampling of basidiomycete genomes demonstrates inadequacy of the white-rot/brown-rot paradigm for wood decay fungi. Proc Natl Acad Sci USA. 2014;111:9923-8.

29. Salvachúa D, Prieto A, Martínez ÁT, Martínez MJ. Characterization of a novel dye-decolorizing peroxidase (DyP)-type enzyme from Irpex lacteus and its application in enzymatic hydrolysis of wheat straw. Appl Environ Microbiol. 2013;79:4316-24

30. Franken ACW, Lokman BC, Ram AFJ, Punt PJ, van den Hondel CAMJJ, de Weert $\mathrm{S}$. Heme biosynthesis and its regulation: towards understanding and improvement of heme biosynthesis in filamentous fungi. Appl Microbiol Biotechnol. 2011;91:447-60.

31. Conesa A, van den Hondel CAMJJ, Punt PJ. Studies on the production of fungal peroxidases in Aspergillus niger. Appl Environ Microbiol. 2000;66:3016-23.

32. Dekker RFH, Vasconcelos A-FD, Barbosa AM, Giese EC, PaccolaMeirelles $L$. A new role for veratryl alcohol: regulation of synthesis of lignocellulose-degrading enzymes in the ligninolytic ascomyceteous fungus, Botryosphaeria sp.; influence of carbon source. Biotechnol Lett. 2001:23:1987-93.

33. Lapadatescu C, Ginies C, Le Quere JL, Bonnarme P. Novel scheme for biosynthesis of aryl metabolites from L-phenylalanine in the fungus Bjerkandera adusta. Appl Environ Microbiol. 2000;66:1517-22.

34. Mäkelä M, Galkin S, Hatakka A, Lundell T. Production of organic acids and oxalate decarboxylase in lignin-degrading white rot fungi. Enzyme Microb Tech. 2002;30:542-9.

35. Morin E, Kohler A, Baker AR, Foulongne-Oriol M, Lombard V, Nagy LG, Ohm RA, Patyshakuliyeva A, Brun A, Aerts AL, et al. Genome sequence of the button mushroom Agaricus bisporus reveals mechanisms governing adaptation to a humic-rich ecological niche. Proc Natl Acad Sci USA. 2012;109:17501-6.

36. Chen W, Lee MK, Jefcoate C, Kim SC, Chen F, Yu JH. Fungal cytochrome p450 monooxygenases: their distribution, structure, functions, family expansion, and evolutionary origin. Genome Biol Evol. 2014;6:1620-34.

37. Doddapaneni H, Chakraborty R, Yadav JS. Genome-wide structural and evolutionary analysis of the P450 monooxygenase genes (P450ome) in the white rot fungus Phanerochaete chrysosporium: evidence for gene duplications and extensive gene clustering. BMC Genom. 2005;6:92.

38. Fernandez-Fueyo E, Ruiz-Duenas FJ, Ferreira P, Floudas D, Hibbett DS, Canessa P, Larrondo LF, James TY, Seelenfreund D, Lobos S, et al. Comparative genomics of Ceriporiopsis subvermispora and Phanerochaete chrysosporium provide insight into selective ligninolysis. Proc Natl Acad Sci USA. 2012;109:5458-63.

39. Quinlan RJ, Sweeney MD, Lo Leggio L, Otten H, Poulsen J-CN, Johansen KS, Krogh KBRM, Jørgensen Cl, Tovborg M, Anthonsen A, et al. Insights into the oxidative degradation of cellulose by a copper metalloenzyme that exploits biomass components. Proc Natl Acad Sci USA. 2011;108:15079-84

40. Hemsworth GR, Johnston EM, Davies GJ, Walton PH. Lytic polysaccharide monooxygenases in biomass conversion. Trends Biotechnol. 2015:33:747-61.

41. Agger JW, Isaksen T, Varnai A, Vidal-Melgosa S, Willats WG, Ludwig R, Horn SJ, Eijsink VG, Westereng B. Discovery of LPMO activity on hemicelluloses shows the importance of oxidative processes in plant cell wall degradation. Proc Natl Acad Sci USA. 2014:111:6287-92.

42. Bennati-Granier C, Garajova S, Champion C, Grisel S, Haon M, Zhou S, Fanuel M, Ropartz D, Rogniaux H, Gimbert I, et al. Substrate specificity and regioselectivity of fungal AA9 lytic polysaccharide monooxygenases secreted by Podospora anserina. Biotechnol Biofuels. 2015;8:90.

43. Hofrichter M. Review: lignin conversion by manganese peroxidase (MnP). Enzyme Microb Technol. 2002;30:454-66. 
44. Hammel KE, Kapich AN, Jensen KA, Ryan ZC. Reactive oxygen species as agents of wood decay by fungi. Enzyme Microb Technol. 2002;30:445-53.

45. Gomez-Toribio V, Garcia-Martin AB, Martinez MJ, Martinez AT, Guillen F. Induction of extracellular hydroxyl radical production by white-rot fungi through quinone redox cycling. Appl Environ Microbiol. 2009;75:3944-53.

46. Martinez D, Challacombe J, Morgenstern I, Hibbett D, Schmoll M, Kubicek CP, Ferreira P, Ruiz-Duenas FJ, Martinez AT, Kersten P, et al. Genome, transcriptome, and secretome analysis of wood decay fungus Postia placenta supports unique mechanisms of lignocellulose conversion. Proc Natl Acad Sci USA. 2009;106:1954-9.

47. Jensen KA, Houtman CJ, Ryan ZC, Hammel KE. Pathways for extracellular fenton chemistry in the brown rot basidiomycete Gloeophyllum trabeum. Appl Environ Microbiol. 2001;67:2705-11.

48. Macdonald J, Master ER. Time-dependent profiles of transcripts encoding lignocellulose-modifying enzymes of the white rot fungus Phanerochaete carnosa grown on multiple wood substrates. Appl Environ Microbiol. 2012;78:1596-600.

49. Langston JA, Shaghasi T, Abbate E, Xu F, Vlasenko E, Sweeney MD. Oxidoreductive cellulose depolymerization by the enzymes cellobiose dehydrogenase and glycoside hydrolase 61. Appl Environ Microbiol. 2011;77:7007-15

50. Cameron MD, Aust SD. Cellobiose dehydrogenase-an extracellular fungal flavocytochrome. Enzyme Microb Technol. 2001;28:129-38.

51. Dodd D, Cann IK. Enzymatic deconstruction of xylan for biofuel production. Glob Change Biol Bioenergy. 2009;1:2-17.

52. Qin X, Zhang J, Zhang X, Yang Y. Induction, purification and characterization of a novel manganese peroxidase from Irpex lacteus CD2 and its application in the decolorization of different types of dye. PLoS ONE. 2014:9:e113282.

53. Moktali V, Park J, Fedorova-Abrams ND, Park B, Choi J, Lee YH, Kang S. Systematic and searchable classification of cytochrome $\mathrm{P} 450$ proteins encoded by fungal and oomycete genomes. BMC Genom. 2012;13:525.

54. Harris PV, Welner D, McFarland KC, Re E, Navarro Poulsen J-C, Brown K, Salbo R, Ding H, Vlasenko E, Merino S, et al. Stimulation of lignocellulosic biomass hydrolysis by proteins of glycoside hydrolase family 61: structure and function of a large, enigmatic family. Biochemistry. 2010;49:3305-16.

55. Qin X, Sun X, Huang H, Bai Y, Wang Y, Luo H, Yao B, Zhang X, Su X. Oxidation of a non-phenolic lignin model compound by two Irpex lacteus manganese peroxidases: evidence for implication of carboxylate and radicals. Biotechnol Biofuels. 2017;10:103.

56. Chen WT, Zheng LL, Jia R, Wang N. Cloning and expression of a new manganese peroxidase from Irpex lacteus F17 and its application in decolorization of reactive black 5. Process Biochem. 2015;50:1748-59.

57. Yang XT, Zheng JZ, Lu YM, Jia R. Degradation and detoxification of the triphenylmethane dye malachite green catalyzed by crude manganese peroxidase from Irpex lacteus F17. Environ Sci Pollut Res. 2016;23:9585-97.

58. Rosenberg MS, Kumar S. Taxon sampling, bioinformatics, and phylogenomics. Syst Biol. 2003;52:119-24.

59. Wu S, Xiong J, Yu Y. Taxonomic resolutions based on 18 S rRNA genes: a case study of subclass Copepoda. PLoS ONE. 2015;10:e0131498.

60. S-i Eyun. Phylogenomic analysis of Copepoda (Arthropoda, Crustacea) reveals unexpected similarities with earlier proposed morphological phylogenies. BMC Evol Biol. 2017;17:23.

61. Song L, Ma F, Zeng Y, Zhang X, Yu H. The promoting effects of manganese on biological pretreatment with Irpex lacteus and enzymatic hydrolysis of corn stover. Bioresour Technol. 2013;135:89-92.

62. Hofrichter M. Review: lignin conversion by manganese peroxidase (MnP). Enzyme Microbial Technol. 2002;30:454-66.

63. Xu C, Ma F, Zhang X. Lignocellulose degradation and enzyme production by Irpex lacteus CD2 during solid-state fermentation of corn stover. J Biosci Bioeng. 2009;108:372-5

64. Dashtban M, Schraft H, Syed TA, Qin W. Fungal biodegradation and enzymatic modification of lignin. Int J Biochem Mol Biol. 2010;1:36-50.
65. Tanaka H, Yoshida G, Baba Y, Matsumura K, Wasada H, Murata J, Agawa M, Itakura S, Enoki A. Characterization of a hydroxyl-radical-producing glycoprotein and its presumptive genes from the white-rot basidiomycete Phanerochaete chrysosporium. J Biotechnol. 2007;128:500-11.

66. Salvachúa D, Martínez AT, Tien M, López-Lucendo MF, García F, de los Ríos V, Martínez MJ, Prieto A. Differential proteomic analysis of the secretome of Irpex lacteus and other white-rot fungi during wheat straw pretreatment. Biotechnol Biofuels. 2013;6:115.

67. Bao D, Gong M, Zheng $H$, Chen M, Zhang L, Wang H, Jiang J, Wu L, Zhu $Y$, Zhu G, et al. Sequencing and comparative analysis of the straw mushroom (Volvariella volvacea) genome. PLoS ONE. 2013;8:e58294.

68. Chin C-S, Alexander DH, Marks P, Klammer AA, Drake J, Heiner C, Clum A, Copeland A, Huddleston J, Eichler EE, et al. Nonhybrid, finished microbial genome assemblies from long-read SMRT sequencing data. Nat Methods. 2013;10:563-9.

69. Haas BJ, Salzberg SL, Zhu W, Pertea M, Allen JE, Orvis J, White O, Buell CR, Wortman JR. Automated eukaryotic gene structure annotation using EVidenceModeler and the program to assemble spliced alignments. Genome Biol. 2008;9:R7.

70. Lowe TM, Eddy SR. tRNAscan-SE: a program for improved detection of transfer RNA genes in genomic sequence. Nucleic Acids Res. 1997;25:955-64.

71. Lagesen $\mathrm{K}$, Hallin P, Rødland EA, Stærfeldt H-H, Rognes T, Ussery DW. RNAmmer: consistent and rapid annotation of ribosomal RNA genes. Nucleic Acids Res. 2007:35:3100-8.

72. Price MN, Dehal PS, Arkin AP. FastTree: computing large minimum evolution trees with profiles instead of a distance matrix. Mol Biol Evol. 2009;26:1641-50

73. Katoh K, Misawa K, Kuma K, Miyata T. MAFFT: a novel method for rapid multiple sequence alignment based on fast Fourier transform. Nucleic Acids Res. 2002;30:3059-66.

74. Passardi F, Theiler G, Zamocky M, Cosio C, Rouhier N, Teixera F, MargisPinheiro M, loannidis V, Penel C, Falquet L, Dunand C. PeroxiBase: the peroxidase database. Phytochemistry. 2007;68:1605-11.

75. Sluiter A, Hames B, Ruiz R, Scarlata C, Sluiter J, Templeton D, Crocker D. Determination of structural carbohydrates and lignin in biomass. In: National Renewable Energy Laboratory Technical Report NREL/TP-51042618. Washington DC: NREL; 2008.

76. Ludwig R, Salamon A, Varga J, Zámocky M, Peterbauer CK, Kulbe KD, Haltrich D. Characterisation of cellobiose dehydrogenases from the white-rot fungi Trametes pubescens and Trametes villosa. Appl Microbiol Biotechnol. 2004;64:213-22.

77. Lee MH, Hong KS, Malhotra S, Park J-H, Hwang EC, Choi HK, Kim YS, Tao W, Lee S-W. A new esterase EstD2 isolated from plant rhizosphere soil metagenome. Appl Microbiol Biotechnol. 2010;88:1125-34.

78. Bolger AM, Lohse M, Usadel B. Trimmomatic: a flexible trimmer for Illumina sequence data. Bioinformatics. 2014:30:2114-20.

79. Trapnell C, Roberts A, Goff L, Pertea G, Kim D, Kelley DR, Pimentel H, Salzberg SL, Rinn JL, Pachter L. Differential gene and transcript expression analysis of RNA-seq experiments with TopHat and Cufflinks. Nat Protoc. 2012;7:562.

80. Mortazavi A, Williams BA, McCue K, Schaeffer L, Wold B. Mapping and quantifying mammalian transcriptomes by RNA-Seq. Nat Methods. 2008;5:621

81. Robinson MD, McCarthy DJ, Smyth GK. edgeR: a bioconductor package for differential expression analysis of digital gene expression data. Bioinformatics. 2010;26:139-40.

82. Livak KJ, Schmittgen TD. Analysis of relative gene expression data using real-time quantitative PCR and the $2^{-\triangle \Delta C T}$ method. Methods. 2001:25:402-8. 